\title{
From Pleasure to Menace: Noel Coward, Harold Pinter, and Critical Narratives
}

\section{Jackson F. Ayres}

For many, if not most, scholars of twentieth century British drama, the playwrights Noel Coward and Harold Pinter belong in entirely separate categories: Coward, a traditional, "drawing room dramatist," and Pinter, an angry revolutionary redefining British theatre. In short, Coward is often used to describe what Pinter is not. Yet, this strict differentiation is curious when one considers how the two playwrights viewed each other's work. Coward frequently praised Pinter, going so far as to christen him as his successor in the use of language on the British stage. Likewise, Pinter has publicly stated his admiration of Coward, even directing a 1976 production of Coward's Blithe Spirit (1941).

Still, regardless of their mutual respect, the placement of Coward and Pinter within a shared theatrical lineage is, at the very least, uncommon in the current critical status quo. Resistance may reside in their lack of overt similarities, but likely also in the seemingly impenetrable dividing line created by the premiere of John Osborne's Look Back in Anger on May 8, 1956. In his book, 1956 and All That (1999), Dan Rebellato convincingly argues that Osborne's play created such a critical sensation that eventually " 1956 becomes year zero, and time seems to flow both forward and backward from it," giving the impression that "modern British theatre divides into two eras." Coward contributed to this partially generational divide by frequently railing against so-called New Movement authors, particularly Samuel Beckett and Eugene Ionesco, for being self-important and tedious.

Despite these criticisms, however, he was generous to other young playwrights, especially Pinter. Although initially unimpressed with Pinter's work, after seeing The Caretaker in May 1960 Coward began to "think [he was] on to Pinter's wavelength."2 In return, Pinter-in addition to directing Blithe Spirit-has frequently commented upon his admiration for Coward, and even initiated a written correspondence with Coward in 1962. Pinter's original letter was a funding request for Caretaker Films, a collective of which he was a member, but subsequent letters were less formal. In a letter dated 6 August 1965, Pinter expresses gratitude for Coward's kind words about his work, then adding, in a charming Coward-esque way, "I would love to talk to you. Perhaps one day I shall descend by parachute on to your mountain stronghold." In an enthusiastic response, Coward proclaims,

Jackson Ayres is a doctoral candidate in English Literature at the University of Arkansas. His research interests include 20th century American \& British literature, drama, film, the political novel, the role of the intellectual and public intellectualism, and popular culture. 
"Your writing absolutely fascinates me. It is entirely unlike anyone else's. You cheerfully break every rule of the theatre that I was brought up to believe in, except the cardinal one of never boring for a split-second. ${ }^{\prime 4}$ Coward and Pinter's effusive mutual respect suggests that not all (if any) established dramatists were wholly resistant to newer, experimental plays, and that younger writers did not altogether reject the theatrical establishment.

The two playwrights' high regard for each other's work prompts us to reevaluate their plays in comparison, and challenge the conventional assumptions of many drama critics and scholars. Indeed, since critics tend to either place Pinter's work as social realism, or follow Martin Esslin's designation of him as an Absurdist, ${ }^{5}$ in opposition to Coward's "stylish [comedies] of manners . . . designed to reassure the self-applauding middle-class patrons," "there has been relatively little research seriously examining connections between them. By no means do all critics deny or entirely ignore the Coward-Pinter relationship. In fact, Barry Day claims, with respect to Coward and Pinter's correspondence, that "[i]n the years that followed more and more commentators came to understand the unlikely professional rapport between the two writers." 7 Day's comment is to a certain extent true, as "commentators" including Christopher Innes, Sheriden Morley, Francesca Coppa, and Peter Hall have indeed recognized the connection; however, Day's observation is also a bit overstated, as few pursue Coward and Pinter's "rapport" in much, or any, detail. For instance, Coppa notes that comic playwrights "such as Noel Coward ... understood Pinter's dramatic project most immediately and instinctively," yet does not elaborate upon this point by drawing any direct lines between the authors. Also, although Innes acknowledges that Coward's dramatic minimalism, "as well as the obliquity in [his] dialogue, leads straight to Harold Pinter," Innes does not fully develop these linkages. Indeed, Innes does fruitfully hint at many important intersections between the work of Coward and Pinter, but none are truly fleshed out. So, even among those scholars who perceive links between Coward and Pinter, little comprehensive examination exists.

Nonetheless, as an important critic who has acknowledged the Coward-Pinter relationship, Innes provides the springboard for a number of connections that I will develop; he also succinctly reminds us why such a project is necessary. Early in his comprehensive study, Modern British Drama: The Twentieth Century (2002), Innes states the frequently ignored fact that "there is no single line of evolution in British drama. Nor is there a distinct succession of periods." Despite this truism, Innes further notes "[c]ritical studies customarily treat the century as if it were composed of distinct units ... [y] et even those periods bounded by major historical events are not self-contained" and "[e]ven within a single generation there are contrasting lines of development." ${ }^{\prime 10}$ Unfortunately, many scholars still insist on perceiving distinct breaks in continuity in dramatic styles, often imposing rigid delimitations upon a messy and fluid historical process for the sake of a neat, convenient line 
of development.

Following Innes, I reject the false premise of a neatly demarcated twentieth century, and dispute the critical narrative that leaves the Coward-Pinter relationship largely unexplored. To do so, I will establish that Coward and Pinter share three dramatic strategies: (1) an approach to language, hinging on subtext and context; (2) a deliberate control of theatre's artifice, preventing the work of either from being labeled "realism," yet without becoming Absurdist or metatheatrical; and (3) a purpose for employing dialogue, relying on tension, even confrontation, in order to define values and establish power relations. I do not claim that these characteristics are exclusive to Coward and Pinter; nonetheless, they serve as significant, yet generally unnoticed, intersections between their plays, and may partly explain their mutual respect. More importantly, these shared qualities complicate simplified critical narratives that are often taken for granted, and they also force us to question the tendency to locate clean discontinuities and orderly classifications within the study of British drama.

In this study, these common strategies will be identified within specific periods of the playwrights' lengthy and diverse dramatic careers. The decision to look at what are commonly known as Pinter's "comedies of menace" is primarily dictated by the year of Coward's death. Considering that their affinities for each other are the motivation for inquiry, and since Coward died in 1973, the last possible new Pinter play he could have seen would have been Old Times (1971). Interestingly, the last Pinter play Coward writes of attending in his diaries is The Homecoming (1965), which he describes as "an extraordinary play." 11 This reference is significant, as this play is generally seen as a turning point in Pinter's writing, a shift the author confirms: "I felt that after The Homecoming . . . I couldn't any longer stay in the room with this bunch of people who opened doors and came in and out. [Subsequent plays] are in a very different form." 12 Simply put, The Homecoming marks the end of Pinter's “comedy of menace" period, which is, by virtue of its chronologic location in Pinter's career, undoubtedly the phase being referenced when Coward expresses admiration.

The rationale behind the "phase" of Coward's career to examine is slightly less precise, but begins with Blithe Spirit. The energy required of Pinter to direct this play, which he confesses was surprisingly difficult, ${ }^{13}$ suggests he found within it something worthwhile. Using that 1941 play as a starting point, it is reasonable to move backwards toward the most representative phase of Coward's career, since "The Master," - as an artist who "epitomizes the Jazz Age of the 1920s and 1930 s"14 - is generally recognized as being at his most incisive and insightful during the interwar period. Taking these sets of plays from Coward and Pinter together, we discover a host of generally unacknowledged dramatic similarities, beginning with the most pronounced of the three shared strategies: their uses of subtext.

As actors themselves, both Coward and Pinter were quite familiar with the 
importance of subtext. Of course, a distinction regarding the term "subtext" is necessary, as a subtext can be found behind every line of any play. Yet, in her study of Pinter's work, Susan Hollis Merritt reminds us of the "two definitions of subtext: ' 1 . the complex of feelings, motives, etc. conceived of by an actor as underlying the actual words and actions of the character being portrayed [and ] 2. an underlying meaning, theme, etc.' In the first sense underlying means motivating; whereas in the second one underlying suggests referentiality." 15 Of subtext's two meanings, "referentiality" in the dialogue of Coward and Pinter is crucial; on the other hand, motivation beyond that referentiality is almost nonexistent.

While these two definitions of subtext can typically be seen as distinct operations, in nearly every case the "underlying meaning" in the dialogue of a Coward or Pinter play exposes the motivation for employing it. They are in fact one and the same. George E. Wellwarth notes the self-contained nature of Pinter's plays: "The actors find their characterizations in the lines . . To seek motivations through memory recall or through attempted connections with the external world would be ruinous to the production. There is no place in a Pinter play for the Method actor, in other words." "Similarly, Coward frequently scoffed at popular "jargons" about motivation: "If a young actor comes up to me, and I'm directing a play, and says, 'What is the motivation of this scene?' well there are one or two answers to that. One is, 'Your salary check next Friday.' The other is, 'If you haven't learned the motivation of the scene when you read the play, then you better not attempt to play it, because you must know that much by now." 17 The first definition of subtext, by and large derived from outside the text, is an interpretive dead end. However, the second definition, which emphasizes an underlying meaning beneath the words - "the unsaid" - is absolutely vital in understanding both the dramatic meanings and purposes behind the playwrights' uses of language.

Coward's language is often described, usually patronizingly or degradingly, as "superficial" and "trivial." Unfortunately, most critics using the terms as epithets have failed to notice that Coward's apparent fixation on the frivolous reflects his understanding of the limitations of language and the power of the unspoken. Sheridan Morley notes that a character in Coward's Shadow Play (1948) "summed [the author's linguistic style] up: 'Small talk, a lot of small talk, with other thoughts going on behind." "Through his characters' frequently trivial-bordering on nonsensical - conversations, Coward is employing "the elliptical twin-level technique .. . which Harold Pinter later adapted to his own darker dramatic purpose: the technique of having a character say one thing while thinking and meaning something entirely different." 18 This technique is exemplified in Coward's masterpiece, Private Lives (1930), where, as Innes explains, "the denial of emotion establishes its presence, [and] expressions of hatred are the coinage of love."19 Such a reversal de-emphasizes language's transcribed meaning in favor of implication and innuendo, a move seen directly in the work of Harold Pinter. 
Pinter's characters, like those of Coward, rarely verbalize their messages explicitly. This point does not suggest that Coward's and Pinter's word choices are arbitrary or irrelevant, since, contextually, they indeed facilitate meaning; however, both rarely write dialogue that plainly articulates feelings and thoughts. In an oft-quoted statement, Pinter once said, "I feel that instead of any inability to communicate there is a deliberate evasion of communication. Communication itself between people is so frightening that ... there is a continual . . . talking about other things rather than what is at the root of their relationship. ${ }^{20}$ Both Coward and Pinter collapse the two meanings of subtext: underlying meanings behind their dialogue do not exist alongside the complex of emotions provoking the words; instead, the underlying meanings are indistinguishable from the motivations.

Consider the banter in Coward's Private Lives, where love is primarilybut not entirely-transmitted through the unsaid implication. In the play, tempestuous divorcées Elyot and Amanda are reunited when honeymooning at the same hotel with equally unsuitable new partners, and they decide to run off together and reignite their relationship. Despite occasionally stating their love, the following exchange is characteristic of their repartée:

Amanda: Have you ever crossed the Sahara on a camel?

Elyot: Frequently. When I was a boy we used to do it all the time.

My grandmother had a lovely seat on a camel. ${ }^{21}$

The dialogue, typically delivered in stylized rapid succession, may initially seem amusing but shallow, a description that generally reflects Coward's post-1956 reputation. Yet, Elyot and Amanda's tête-à-têtes are shallow only if we ignore the fact that "we often speak words which substitute for what we are actually thinking; that the primary function of conversation is often not the exchange of information; [and] that what is understood in conversation differs from the paraphraseable meaning. ${ }^{22}$ Accordingly, anyone who has ever engaged in flirtation will recognize that the couple is not literally discussing desert travel. This observation may seem banal, but it points to a philosophy toward communication and relationships, manifest in dialogue, shared by Pinter. At its most basic, this shared philosophy holds that language is best understood as a tool for defining relationships, and that its deployment has more communicative potential than the language itself. Elyot's flippant response to Amanda's question about desert travel is loving, rather than disrespectful, because he is participating in language play that she will reciprocate. Therefore, the absence of flippancy, seen in literalness, indicates either stultifying conformity or interpersonal disconnection.

The banter between Amanda and Elyot is trivial and silly, but the willingness to participate signals a connection between them. They develop a tennis-like rapport, with their equality in verbal (and physical) sparring highlighting their suitability. 
Contributing to and maintaining the banter indicates a connection, and the refusal to participate - by taking a flippant comment seriously — severs the connection. For example, when Elyot defends his sobriety by claiming he has only had three glasses of brandy, and that "A child of two couldn't get drunk on that," Amanda replies: "On the contrary, a child of two could get violently drunk on only one glass of brandy." ${ }^{23}$ As Jean Chothia notes, "[T] he atmosphere is more effectively cooled than it would have been by a straightforward rebuttal of his untrue claim about how much he had drunk. ${ }^{24}$ Elyot and Amanda use this tactic repeatedly in interactions with their incompatible new spouses. When Sibyl, disgusted at Elyot's infidelity, exclaims that she feels "as though slimy things had been crawling all over me," Elyot remarks, "Maybe they have, that's a very old sofa." ${ }^{25}$ Elyot's response is funny in that he has read Sibyl's abstract statement concretely, but such a rebuttal also has a demeaning, distancing quality.

Communication, then, is located in the unsaid. Victor's and Sibyl's vapid platitudes and Elyot's and Amanda's superficial banter are meaningful in execution, rather than content. I do not mean to imply that Coward's written dialogue is irrelevant or interchangeable; the class distinctions present in Elyot and Amanda's conversation about desert travel is just one example of how their particular words contribute to their characterizations. Yet even that class issue - seen in privileged travel to exotic locales-remains implicit and encoded in trivial conversation. Although language exists as a means of communication, it does not allow direct communication. In Private Lives, we see how meaning is found more in the decision to use certain words than in the words themselves, and how the willingness or refusal to participate in banter regulates relationships. Consequently, when Elyot and Amanda engage each other in flippant verbal jousting, we see the two definitions of subtext merge: love, though left unsaid, is both the meaning and the motivation of the exchange.

Pinter's dialogue, like that of Coward, collapses meaning and motivation, with an emphasis on the implications of speech over the speech itself. Pinter spells out this approach quite plainly in The Homecoming, when Ruth says, "My lips move. Why don't you restrict your observations to that? Perhaps the fact that they move is more significant ... than the words which come through them." ${ }^{\text {26 }}$ This emphasis on speaking rather than speech can be traced to Pinter's first full-length play to be produced, the commercially and critically unsuccessful The Birthday Party (1957). In the play, little is known about boardinghouse tenant Stanley Webber, including why he is confronted and interrogated by McCann and Goldberg, the somewhat vaudevillian representatives of a sinister, unnamed "organization." The ostensibly inane stichomythia they employ when confronting the trapped Stanley is sparse and seemingly devoid of meaning:

Goldberg: You stuff yourself with dry toast. 
McCann: You contaminate womankind.

Goldberg: Why don't you pay the rent?

McCann: Mother defiler!

Goldberg: Why do you pick your nose? ${ }^{27}$

Outwardly, the words being spoken have very little connection to the action of the play, but "the information passing between Pinter's characters moves by way of subtext" with "a heavy baggage of implication, confusion, and nuance." 28 Pinter holds that "we communicate . . . in our silence" and that silence exists both when nothing is uttered and when "a torrent of language is being employed." ${ }^{29}$ McCann and Goldberg unleash a barrage of language upon Stanley that - though it should not be dismissed as interchangeable mumbo-jumbo-is essentially silence, and within that silence is meaning, which is, in this case, intimidation.

We can distinguish the primacy Pinter and Coward give subtext through contrast with a contemporary such as John Osborne, whom many critics align with Pinter. In one of Jimmy Porter's invectives from Look Back in Anger, he sneers, "The old Edwardian brigade do make their brief little world pretty tempting. All home-made cakes and croquet, bright ideas, bright uniforms . . . What a romantic picture. Phoney too, of course." ${ }^{30}$ In terms of subtext, we can certainly locate any number of "motivations" for this passage, particularly in terms of power relations with Jimmy's father-in-law, as well as many "underlying meanings," such as the feelings of helplessness that often undergird angry outbursts. Yet, little in Osborne's play suggests that Jimmy is not speaking the absolute truth (as he sees it) or that there is a perceptible gap between his words and intended meaning. Osborne is the type of writer who "clearly trusts words absolutely" and "who puts forward his concern for you to embrace ... who declares that his heart is in the right place, and ensures it can be seen in full view." Pinter actually warns of this kind of writer because his or her work denies that most language is not "platitudinous, trite, [and] meaningless." ${ }^{31}$ Pinter's linguistic philosophy is antithetical to Osborne's, yet their working class characters, starkness, and harsh tones can make them seem incorrectly affiliated and contribute to the Coward-Pinter divide.

Ultimately, what unifies the linguistic techniques of Coward and Pinter is their understanding of the limitations of the spoken word. Christopher Innes notes this shared recognition, and their awareness of "the fossilization of language." ${ }^{32}$ Innes supports his claim by positing a linguistic continuity for the two playwrights, first citing dialogue from Coward's Design for Living (1933):

Leo: Sherry's a very ludicrous word, isn't it, when you begin to analyse it?

Otto: Any word's ludicrous if you stare at it long enough. Look at "macaroni." 33 
Innes sees this passage as leading directly to the chatter between two gangsters in Pinter's The Dumb Waiter (1960):

Ben: Go and light it.

Gus: Light what?

Ben: The kettle.

Gus: You mean the gas ... How can you light a kettle?

Ben: It's a figure of speech! Light the kettle. It's a figure of speech! . . . It's common usage! ${ }^{34}$

Words have no intrinsic meaning, and so any scrutiny will expose the ultimate purposelessness in assigning them too much importance. Gus and Ben's exchange shows the lack of concrete meaning in language_- "lighting the kettle" can actually mean "lighting the gas" - thereby revealing the indeterminacy within language systems. Both Coward and Pinter are skeptical of the communicative potential of language alone, and so they consistently undermine the literal denotations of words in favor of implication and the unsaid. Meaning is found within a "language cloud" - chatter, nonsense, evasion, silence - rather than being transmitted via a "language ray" that need only be processed and deciphered.

Of course, for one to properly navigate the language cloud the encoded message must be both appropriately performed and understood within its particular context - certainly any comedian or Supreme Court nominee can tell you how decontextualization affects the intended meaning of a statement. Coward is frequently mischaracterized as an epigrammatic writer, often considered Oscar Wilde's theatrical heir. Director Christopher Newton corrects this misconception, noting that Coward's funniest lines are "not funny unless you know the context." 35 Coward reflected that by the time he wrote Private Lives his dialogue had become "less elaborate, and [he] was beginning to concentrate more on the comedy values of situation rather than the comedy values of actual lines." ${ }^{36}$ Certainly many of the play's biggest laughs, such as Amanda's quip, "Very flat, Norfolk," ${ }^{37}$ are rendered meaningless without some notion of context. The line is not a joke independent of the situation, and without the broader discussion about their new spouses to indicate that Amanda is referring to Sibyl, rather than Norfolk, the jibe is stripped of humor and meaning. The observation that Coward's humorous lines are not complete units appreciated equally as either pieces of dialogue or as independent witticisms returns us to the broader concern of Coward's use of the unsaid, since the importance of context comprises - along with their uses of subtext - the first of the three shared strategies between Coward and Pinter.

Just as most of Coward's funny lines lose their humor when extracted from the context, the communicated meaning of his dialogue - found in the unsaid — is under 
the same constraint. Undoubtedly, "context" includes the situation, but also the manner in which it is performed. Coward demonstrates this principle outright when the eccentric Bliss family of Hay Fever (1925) plays the parlor game "Adverbs," in which one player must guess a mystery adverb by having the others perform directives in the manner of the word. For instance, Coward's stage directions explain how Judith performs the chosen word "winsomely" for Sorel to interpret: "She trips lightly over to the vase on the piano, gurgling with coy laughter, selects a flower, then goes over to Richard; pursing her lips into a mock smile, she gives him the flower with a little girlish gasp at her own daring and wags her finger archly at him, and returns to her seat." ${ }^{\prime 38}$ The "Adverbs" scene is emblematic of Coward's best plays: performance over plot; communication aligned with, but not contained within, language; and expressivity over expression.

Similarly, the obliqueness of Pinter's dialogue means that performance and context are inextricably linked to its communicative power. Along these lines, Richard Schechner notes that "the framework around [Pinter's] plays, the 'conceptual world' out of which the plays emerge, is sparse, fragmented." ${ }^{39}$ In The Birthday Party, Pinter provides no explanation as to who Stanley is, why he has been living in Petey and Meg's boarding home, or what organization McCann and Goldberg represent. Initially, many critics decried this ambiguity, claiming the play was incomprehensible. Yet, the lack of explanatory details does not make the play existential or surrealistic, nor is its basic premise unrealistic; as Pinter observes, intimidating figures "out of nowhere . . . arriving at the door, [is something that] has been happening in Europe" for centuries. ${ }^{40}$ More importantly, the empty framework contributes to what Drew Milne calls "a Wittgensteinian interest in disabusing believers in the context-free truth of words. ${ }^{.11}$ This disabuse can be seen in McCann and Goldberg's interrogation of Stanley. Although few stage directions are given, the antiphonal nature of their stichomythia (and their names, reminiscent of the stage Irishman and Jew) harkens back to vaudeville. Their interrogatory "routine," with Stanley's back to the audience turning him into a straight man, is ineptly comprised of "riddles, children's games, [and] music-hall cross-talk" that invariably generates laughter from the audience. ${ }^{42}$ Any enjoyment from the interrogation halts immediately, however, with Stanley's sudden scream. ${ }^{43}$ This jarring outburst, implicating the audience for their earlier amusement, is an unsubtle example of Pinter demonstrating context's crucial, and easily manipulated, relationship to language.

The Homecoming is perhaps the best example of Pinter's collapsing of meaning with motivation, and the way context regulates both. Richard M. Coe identifies three different types of communication existing in the play: "communication in the technical sense that information is transmitted which produces change"; the "successful, conscious transmission of trivial information"; and, most importantly, communication "on the level of relationship ... [with] indications that the characters 
are sometimes aware of these covert communications and act in accordance with their awareness." Uniting these three forms is the presence of a power structure being defined or changed by the act of communication. Communication of the first type, whether conscious or not, occurs whenever there are modifications in the position or behavior of a character, such as Ruth, who "makes a choice which moves her from one situation to another and the dominance relations of the characters are modified accordingly." ${ }^{44}$ The second type - the conscious transmission of trivial information — can best be seen in the beginning of the play when Max attempts to talk about a number of varied trivialities to Lenny, who refuses to acknowledge the communication until, finally, he snaps: "Plug it, will you, you stupid sod, I'm trying to read the paper!"45 This outburst shows that Lenny is clearly aware that his father is speaking, but his unwillingness to respond is an attempt to assert his dominance over Max.

The final type identified by Coe involves relationships. When Lenny demands that Ruth relinquish her glass of water and she responds, "If you take the glass . . . I'll take you," " Ruth is "concerned not with the use-value of the glass, but with its exchange-value as a signifier of power." 47 The neutral function of the water would be to quench thirst, but, as we are unaware if Ruth is actually thirsty or not, Pinter is indicating that the conversation is not actually about the possession of the glass. Throughout the play "the characters' physical actions contradict the socially acceptable platitudes uttered"48; this separation of utterance from related physical action highlights the primacy of the intention and context of the speech act over the literal meaning of the speech itself. Pinter never denies language's ability to convey information, but in most cases the speakers are consciously using their orders, responses, or silences to either assert dominance or undermine the control of others; language functions as a power structure and is grounded overwhelmingly in context and performance.

Curiously, despite their emphases on performance and experiences as actors, both Coward and Pinter believe in the primacy of the author in the theatre-a point of agreement that leads to the second of the playwrights' shared strategies: the firm control, especially over theatre's artifice, they exert over their plays. Pinter has plainly stated that he is in philosophical opposition with Joan Littlewood's belief that the theatre is the actor's domain, ${ }^{49}$ and Coward chastises actors who fail to memorize their lines during rehearsals in an attempt to let their characters/ characterizations grow. ${ }^{50}$ These comments, and the fact that their plays are not drastically misunderstood on the page, signal the complex interplay between language and performance in Coward's and Pinter's works. Actors Juliet Stevenson and Anton Lesser discovered the rigidness in Coward's work as they rehearsed for a production of Private Lives in 1999. Stevenson recalls that "when [they] broke lines up, took pauses on an impulse, [or] imposed [their] own dynamic on the dialogue, 
the scenes didn't work anything like as well." ${ }^{51}$ In a similar vein, Pinter alludes to the "dynamic" of his dialogue while explaining his famous "pauses" and "silences": "They're not formal conveniences or stresses but part of the body of the action. I'm simply suggesting that if they play it properly they will find that a pause - or whatever the hell it is - is inevitable. And a silence equally means that something has happened to create the impossibility of anyone speaking for a certain amount of time-until they can recover from whatever happened before the silence." ${ }^{52}$ Actors and directors who have staged Pinter's work overwhelmingly agree with this contention and that, despite sparse language, his texts are complete. Director Peter Hall insists that Pinter's material is entirely self-contained: "You can't make your own personal comment as an actor. You can't cop out. You can't paraphrase Shakespeare and you can't paraphrase Pinter." ${ }^{53}$ Somewhat paradoxically, Coward's and Pinter's language hinges on performance, yet performances are regulated, even controlled, by the language.

The tight construction of Coward's and Pinter's dialogue leads to a broader analysis of the control, as playwrights, they exert over their work, including their manipulation of theatre's artifice. Of course, the dramatic worlds they create are rarely associated; indeed, Coward's upper-crust stylishness prompts many to think of Oscar Wilde, while Pinter in performance inevitably draws comparisons to Samuel Beckett. The kneejerk association of Pinter with Beckett has been problematic. Yael Zarhy-Levo has convincingly shown that Pinter did not typically receive favorable reviews until after a positive critical consensus on Beckett had been established. Zarhy-Levo writes that "reviewers repeatedly compare Pinter to Beckett and Ionesco, which seems to create the notion that Pinter can be regarded as a British representative of the European avant-garde." ${ }^{54}$ Yet, although he clearly thought quite highly of Beckett, and even sent him drafts to critique, Pinter himself acknowledged that "the only direct influence of Beckett's work on his own [was] 'something of its texture." ${ }_{55}$ This so-called "texture" somehow makes Pinter, especially in performance, seem more like Beckett than a playwright such as Coward, facilitating a critical narrative that mischaracterizes both Pinter and Coward.

Pinter himself does not explain precisely what he means when he refers to "texture," but I would argue that it is derived from his refusal to contextualize the action on the stage, a move that is, ultimately, a simple recognition of the artifice of the theatre. Congruent with Pinter's denial of a context-free truth of words is a denial of a context-free truth of reality. The play's "world," beyond what occurs on stage, is irrelevant because none exists - this view of theatre is shared by Coward, who wrote admiringly to Pinter, "I love your choice of words, your resolute refusal to explain anything and the arrogant, but triumphant demands you make on the audience's imagination." 56 Both writers believe that a play-its meaning, its world, its vitality - should be self-contained. David Edgar's comment that "Coward's plumbing is on the outside ... [and] his plays consist of what they are about" 
could just as accurately describe Pinter's work. Critics must recognize that, in the theatre, "realism" does not exist as an "either/or" proposition, but as a spectrum; as Pinter explains, "If you press me for a definition, I'd say that what goes on in my plays is realistic, but what I'm doing is not realism." 58 Neither author adheres to the strict naturalism found in, for example, the early plays of Arnold Wesker, nor do they venture as far as Beckett does into a theatre that is entirely metaphorical, even existential. Pinter roots his worlds firmly in reality, but his minimalism can sometimes be confused with surrealism. Likewise, Coward is often seen as a failed realist, blithely polishing "reality" with a glossy veneer. Yet, "[m] ost of [Coward's] plays are rooted in period, but not in a society that was ever real," ${ }^{59}$ making them more metaphorical, and critical, than normally assumed. In the end, if one were to graph a "realism scale," the techniques and purposes of Coward and Pinter - in other words, their "styles" - would place them relatively near each other on the chart.

Not only do Coward and Pinter both represent reality on the stage stylistically and theatrically, but many of their plays grapple with content and themes that are surprisingly similar. In Pinter's comedies of menace and the major representative plays of Coward, the relative power within relationships is a recurring and dominant theme, often explored within families (The Homecoming, Hay Fever) and expressed linguistically (Stanley's interrogation in The Birthday Party, verbal jousting in Private Lives). For both playwrights, many of their most acclaimed and popular plays have narratives that primarily demonstrate language's role in shifting power relations and struggles for control, such as Pinter's The Caretaker (1960) and Coward's Blithe Spirit. These two plays represent Coward and Pinter's third shared strategy: the use of dialogue for the purpose of defining values and power relations. In Coward's farce, Charles Condomine's deceased first wife, Elvira, is conjured by that memorable medium, Madame Arcati, during a séance. This summoning creates a love triangle between Elvira, Charles, and his current wife, Ruth, who is later killed and then proceeds to also haunt Charles. The plot and humor are driven by Elvira and Ruth's attempts to one-up the other and attain control of Charles-Elvira orchestrated Ruth's deadly accident in an attempt to kill Charles, so that he would be forced into the spirit realm with her.

Throughout the play, Coward gives us examples of manipulative and controlling behavior in order to suggest that power is at the root of all relationships. According to John Lahr, "Charles Condomine is haunted for his selfishness, and long before the ghosts of his former wives face him with his exploitation, the audience sees him getting ready to exploit Madame Arcati, whom he had cajoled into having a séance at his house so he can observe her for his novel. ${ }^{60}$ In the end, however, it appears Charles manages to gain the final victory. Charles presumes ghosts will be unable to cross the English Channel, so he packs his bags and leaves the country. As he departs, he lets Elvira know of his affairs during their marriage, and to his second wife he says, "I was reasonably faithful to you, Ruth, but I doubt if it would have 
lasted much longer-you were becoming increasingly domineering, you know, and there's nothing more off-putting than that is there?" Charles trumps the two ghosts by shattering any illusions of love, but more importantly, he asserts final dominance by simply leaving the situation — a strategy also employed by Teddy in The Homecoming and Elyot and Amanda at the end of Private Lives. Of course, Charles also notes, "I expect we are bound to meet again one day, but until we do I'm going to enjoy myself as I've never enjoyed myself before." ${ }^{\text {61 }}$ Given that Elvira and Ruth are not above earthly pettiness even after they've crossed over-and the inarguable fact that Charles must eventually join them there-it seems that Coward feels such struggles for power are eternal and inevitable.

The narrative and ending of Pinter's The Caretaker suggest that he feels similarly about the competitive nature of group dynamics. After Aston, apparently with good intentions, allows the tramp Davies to stay in his shabby apartment, a series of games of possession and control ensue between the two and Aston's brother, Mick. As "yet another study in victimization," "62 the play presents a triangular relationship that can only exist as two-against-one. In the end, the brothers Mick and Aston defeat Davies - emotionally, physically, and mentally. In the play's closing moments, Mick is unresponsive and Aston turns his back as Davies begs pathetically: "Listen ... if I . . got down ... if I was to ... get my papers ... would you ... would you let ... would you ... if I got down ... and got my ..." ${ }^{63}$ This contest for dominance appears to be over, with Pinter implying that the game will only end when one participant has been utterly defeated and shattered. Authority and power reside within control, and to some degree all human interaction -including conversation - is the negotiation of control.

The assertions of and struggles for power in the plays of Coward and Pinter are so pervasive that they inform the very realities the characters exist within - that is, the imposition of power is not limited to only those figures on the stage. In Pinter's The Dumb Waiter, the dialogue between Ben and Gus, two assassins awaiting orders, establishes their relative power positions. However, of greater importance is the revelation at the end of the play, when one of the gangsters turns out to be the target, graphically demonstrating that "the menacers themselves are not immune from the system they serve." Amidst all the jockeying for dominance between Gus and Ben, there is the invisible presence of a greater power. Pinter explains that the unseen figure upstairs "is a figure of authority. Gus questions this authority and rebels against it and therefore is squashed at the end, or is about to be squashed." ${ }^{64}$ Here we are dealing with a form of power that cannot be verbalized, as there is no figure present to speak it; instead, that power is the knowledge that amongst petty squabbling is a stronger force that will be imposed. This force could be understood as "society" - or at least the expectations and conventions of society. 
As in The Dumb Waiter, this force manifests itself invisibly in Coward's Design for Living, a play in which, according to Pinter, Coward "questions the social structures in no uncertain terms. He just turns them upside down." 65 The play concerns a love triangle between three artists: Leo, Gilda, and Otto. However, the triangle is complicated in that every participant is in love with the other two and - then, as to a lesser degree today - societal conventions dictate that intimate relationships be in heterosexual pairs. Although Design for Living ends with the three principals embracing an unorthodox three-way relationship, it would be a mistake to read the play as a victory over stifling traditional values. The final lines of the play belong to Ernest, the conventional art dealer. He calls the trio "degenerates" and screams, "You're shifty and irresponsible and abominable, and I don't wish to set eyes on you again — as long as I live!" Meanwhile, the final stage directions call for Leo, Gilda, and Otto, to "groan and weep with laughter," ${ }^{66}$ which echoes as the curtain falls. Rather than uproarious and liberating, the haunting laughter reverberating from the stage comes "in a highly discomforting and exaggerated form." Although there is a presumed rejection of conformity, "the only solution offered by Design for Living is purely aesthetic," and therefore the title ends up being "ironic . . . rather than prescriptive." ${ }^{\circ 7}$ A wry pessimism prevents Design for Living from being too joyous: no substantive alternative is presented amid the egoism of the three artists, and the eerie laughter fatalistically suggests that the "design" for their new lifestyle is doomed.

Just as the unseen authority figure in The Dumb Waiter manages to control those who exist outside of society's rules, the invisible specter of conformity looms over Design for Living and promises to stifle any attempt to break free. Furthermore, the ambiguity in these two plays draws attention to their authors' comic sensibilities. Innes notes that, despite being labeled both an existential Absurdist and a political writer (only the latter being fully true), "the overriding tone of [Pinter's] work is comic, and even his political pieces retain an undidactic detachment." Coward's cool detachment, rather than ignored like Pinter's, is typically overemphasized and mischaracterized as proof of his lack of depth. Yet, Coward-like Oscar Wilde - knew that flippancy is the only way to criticize society without a dogmatic, authoritarian, and easily co-opted diatribe. ${ }^{68}$ Both writers explore themes of power wielded through language, yet also strive to prevent their own language from turning authoritarian.

This shared comic sense is, upon inspection, one mere facet of the strong relationship that exists between Coward and Pinter, perhaps at least partly explaining their stated admiration for each other. This comic sense relates to common themes of power and control, as well the role of language in defining values and establishing dominance in personal relationships. Moreover, neither author finds language's ability to convey meaning and regulate interpersonal relationships within 
any intrinsic property of language itself. Both deprive language of any inherent communicative power, demonstrating how communication is found in subtext and is utterly context-dependent. Their preoccupations with context connect to their deliberate, but restrained, manipulations of theatre's artifice. Coward and Pinter both exploit drama's artificiality and are unapologetically theatrical in order to represent more accurately particular social worlds, revealing their natures as selfcontained and context-dependent.

Certainly Coward and Pinter aren't alone in their uses of these strategies; indeed, many modern playwrights share these dramatic qualities to various degrees. Using language as a means of both resistance and control can be seen in the work of Brian Friel; the self-consciously theatrical manipulation of theatre's artifice is a highlight of Joe Orton's work; and communication's dependence upon subtext and context leads us to the American playwright David Mamet, to cite just a few examples. I am not arguing that Coward and Pinter form a separate category, but rather that they, by and large, exist in many overlapping categories. Unfortunately, the desires for clean dividing lines, broad - therefore compelling and appealinggeneralization, and a preoccupation with somewhat superficial distinctions have caused too many drama scholars to, more often than not, deny, ignore, or gloss over the Coward-Pinter connection. The sweeping and head-spinning way such a critical redirection can happen is exemplified in an observation by Terrence Rattigan, who, despite the quality and continued popularity of his work, is still generally disparaged by critics: "There I was in 1956, a reasonably successful playwright with Separate Tables just opened, and suddenly the whole Royal Court thing [George Divine's 'new writers' season that produced Osborne] exploded, and Coward and Priestley and I were all dismissed, sacked by the critics." Yet, Innes reminds us that critics mustn't lose sight of the fact that "any historical continuum ... is open-ended. [Critical certainty] may be challenged by revisionists who reveal the importance of plays that have been overlooked" and new plays perpetually reconfigure the field. ${ }^{69}$ To this end, this critical reevaluation simultaneously questions fundamental assumptions within the scholarship of twentieth century British drama and offers new perspectives on both Coward and Pinter by looking at their work together.

Superficially, Coward and Pinter seem to exist on two separate lines of development, separated by 1956 and John Osborne. Even though Coward's plays remain popular among audiences, and increasingly scholars are writing admiringly of his progressive views on matters such as politics, gender, and sexuality, ${ }^{70}$ in many ways Coward remains haunted by the perception that he is a relatively shallow, middlebrow relic of the interwar period with a "talent to amuse." According to Innes, "Like Terrence Rattigan, though even more unjustly, [Coward] was rejected as an Establishment figure by the new wave of British dramatists who arrived in the mid-1950s, and dominated the scene well into the 1970s." 71 Although it has diminished, this middlebrow specter still lingers around Coward. Pinter, on the other 
hand, was unfavorably received by critics, but upon his alignment with Beckett and the Absurdists, his critical reputation has steadily elevated; his winning of the Nobel Prize in 2005 and death in 2008 have only increased the prestige of, and interest in, his work. Upon consideration of their mutual admiration, however, we see that Coward prefigures Pinter and many other subsequent playwrights, and the borders of the theatrical canon need to be redrawn.

Thankfully, canon borders are fluid, and examining underdeveloped connections between playwrights is an effective means to revise inaccurate canon demarcations and simplified critical narratives. Yael Zarhy-Levo argues, "Accepting a new playwright into the theatrical canon involves, in fact, the affiliation of the new playwright with theatrical schools and/or dramatic styles which have already been accepted. As such, new acceptance plays a determining factor in canon formation and canon borders as well as in the definition of theatrical schools and historical sequence." ${ }^{72}$ This relationship can also operate backwards in the creation of critical narratives, and now - as more critics acknowledge Coward's and Pinter's affinities for each other's work - is an opportune moment to revise the critical tendency to place the two playwrights into separate theatrical lineages. The Coward-Pinter relationship must be fully explored and examined in order to both understand each writer's work in new ways and further erode simplified critical narratives.

\section{Notes}

1. Dan Rebellato, 1956 and All That: The Making of Modern British Drama (London: Routledge, 1999) 4

2. Noel Coward, The Noel Coward Diaries, ed. Graham Payn and Sheridan Morley (London: Weidenfeld and Nicolson, 1982) 436.

3. Harold Pinter, The Letters of Noel Coward, ed. Barry Day (New York: Knopf, 2007) 243.

4. Noel Coward, Letters 243.

5. Yael Zarhy-Levo, "Pinter and the critics," The Cambridge Companion to Harold Pinter, ed. Peter Raby (Cambridge: Cambridge UP, 2001) 215.

6. Ronald Knowles, "Pinter and twentieth-century drama," The Cambridge Companion to Harold Pinter, ed. Peter Raby (Cambridge: Cambridge UP, 2001) 73.

7. Barry Day Letters 244.

8. Francesca Coppa, "The sacred joke: comedy and politics in Pinter's early plays," The Cambridge Companion to Harold Pinter, ed. Peter Raby (Cambridge: Cambridge UP, 2001) 44.

9. Christopher Innes, Modern British Drama: The Twentieth Century, (Cambridge: Cambridge UP, 2002) 281.

10. $7-8$.

11. Coward, Diaries 605.

12. Katherine H. Burkman, The Dramatic World of Harold Pinter: Its Basis in Ritual (Columbia: The Ohio State UP, 1971) 141.

13. Mel Gussow, Conversations with Pinter (London: Nick Hern Books, 1994) 61.

14. Innes, Modern British Drama 271.

15. Susan Hollis Merritt, Pinter in Play: Critical Strategies and the Plays of Harold Pinter (Durham: Duke UP, 1990) 142.

16. George E. Wellwarth, “The Dumb Waiter, The Collection, The Lover, and The Homecoming: A Revisionist Approach," Harold Pinter: A Casebook, ed. Lois Gordon (New York: Garland, 1990) 99-100. 

1961.

17. "Interview with Noel Coward," Talking of Theatre, int. Walter Harris, BBC Radio, 19 Sept.

18. Sheridan Morley, "Introduction," Collected Plays: One, by Noel Coward (London: Methuen, 1999) xv, xiv.

19. Innes, Modern British Drama 281.

20. "Interview with Harold Pinter," People Today, int. Kenneth Tynan, BBC Radio, 28 Oct. 1960.

21. Noel Coward, Private Lives, Collected Plays: Two (London: Methuen, 2003) 32.

22. Jean Chothia, "Playing With the Audience," Look Back in Pleasure: Noel Coward Reconsidered, eds. Joel Kaplan and Sheila Stowell (London: Methuen, 2000) 110.

23. Coward, Private Lives 47.

24. Chothia, "Playing With the Audience" 111.

25. Coward, Private Lives 54

26. Pinter, The Homecoming (New York: Grove, 1965) 53.

27. Harold Pinter, The Birthday Party, Plays: One (London: Faber and Faber, 1991) 45.

28. Richard Schechner, "Puzzling Pinter," The Tulane Drama Review 11 (1966): 176, JSTOR, 7 Jul 2006 http://www.jstor.org/.

29. Harold Pinter, "Introduction: Writing for the Theatre," Plays: One (London: Faber and Faber, 1991) xiii.

30. John Osborne, Look Back in Anger (Harmondsworth: Penguin, 1957) 17.

31. Pinter, "Introduction: Writing for the Theatre," xi, xiii.

32. Innes, Modern British Drama 281.

33. Noel Coward, Design for Living, Collected Plays: Three (London: Methuen, 1999) 68-69.

34. Harold Pinter, The Dumb Waiter, Plays: One (London: Faber and Faber, 1991) 125.

35. "Round Table," Look Back in Pleasure: Noel Coward Reconsidered, eds. Joel Kaplan and Sheila Stowell (London: Methuen, 2000) 188.

36. Chothia, "Playing With the Audience" 103.

37. Coward, Private Lives 23.

38. Noel Coward, Hay Fever, Collected Plays: One (London: Methuen, 1999) 37.

39. Richard Schechner, "Puzzling Pinter," 177.

40. Quoted in Innes, Modern British Drama 332.

41. Drew Milne, "Pinter's Sexual Politics," The Cambridge Companion to Harold Pinter, ed. Peter Raby (Cambridge: Cambridge UP, 2001) 198.

42. Innes, Modern British Drama 335

43. Pinter, The Birthday Party, 46.

44. Richard M. Coe, "Logic, Paradox, and Pinter's Homecoming," Educational Theatre Journal 27 (1975): 488-9, JSTOR, 6 Aug 2006, http://www.jstor.org/.

45. Harold Pinter, The Homecoming 9.

46. 34.

47. Coe, "Logic, Paradox, and Pinter's Homecoming" 489.

48. Innes, Modern British Drama 345.

49. "Interview with Harold Pinter."

50. "Interview with Noel Coward."

51. Russell Jackson, int. with Juliet Stevenson, Look Back in Pleasure: Noel Coward Reconsidered, eds. Joel Kaplan and Sheila Stowell (London: Methuen, 2000) 213.

52. Gussow, Conversations with Pinter 36.

53. Burkman, The Dramatic World of Harold Pinter 123.

54. Zarhy-Levo, "Pinter and the critics" 215.

55. Innes, Modern British Drama 330.

56. Coward, Letters 243.

57. David Edgar, "Noel Coward and the Transformation of British Comedy," Look Back in Pleasure: Noel Coward Reconsidered, eds. Joel Kaplan and Sheila Stowell (London: Methuen, 2000) 13.

58. Burkman, The Dramatic World of Harold Pinter 119.

59. Maria Aitken, interview with J. Kaplan, Look Back in Pleasure: Noel Coward Reconsidered, eds. Joel Kaplan and Sheila Stowell (London: Methuen, 2000) 200.

60. John Lahr, Coward the Playwright (London: Methuen, 1982) 117.

61. Noel Coward, Blithe Spirit, Collected Plays: Four (London: Methuen, 1999) 131.

62. Innes, Modern British Drama 339. 
63. Harold Pinter, The Caretaker, Complete Works: Two (New York: Grove P, 1977) 87.

64. Innes, Modern British Drama 337, 338.

65. Changing Stages, Part IV: 1956, prod. Richard Eyre, PBS/BBC, 2001.

66. Coward, Design for Living 95.

67. Innes, Modern British Drama 273.

68. 10,264

69. $76,12$.

70. See, for example: Penny Farfan, "Noel Coward and Sexual Modernism: Private Lives as Queer Comedy," Modern Drama 48 (2005) 677-688.

71. Innes, Modern British Drama 283.

72. Yael Zarhy-Levo, "Critical Modes and the 'Rebellious' Playwright: Pinter's Alaska, Stoppard's Arcadia," Journal of Dramatic Theory and Criticism 16 (2001) 82. 